\title{
RADIOCARBON CHRONOLOGY OF PREHISTORIC CAMPSITES IN ALPINE AND SUBALPINE ZONES AT HALEAKALĀ, MAUI ISLAND, USA
}

\author{
Mike T Carson \\ International Archaeological Research Institute, Inc., 2081 Young Street, Honolulu, Hawai'i 96826, USA. \\ Corresponding author. Email: mcarson@ iarii.org. \\ Melanie A Mintmier \\ Department of Anthropology, University of Hawai'i at Mānoa, 2424 Maile Way, Saunders Hall 346, Honolulu, Hawai'i \\ 96822, USA.
}

\begin{abstract}
A chronological synthesis of prehistoric campsites in alpine and subalpine zones $(\sim 2-3 \mathrm{~km}$ asl $)$ at Haleakalā, Maui Island, USA, is based on relative stratigraphy from 24 test excavations, associated artifacts of known or probable time periods, and 12 radiocarbon dates. The results indicate intensive use of the unfavorable high-altitude environment in the range of AD 1400-1600, with very limited use slightly earlier. Numerous campsites were used repeatedly near the Haleakalā crater rim and scattered on the lower western mountain slope. Prior to this time, activity in this inhospitable setting was infrequent and occurred on a small scale.
\end{abstract}

\section{INTRODUCTION}

Archaeological site documentation and test excavation provide scientific data concerning precontact Hawaiian activities in alpine and subalpine zones on the outward western slope of Haleakalā, Maui Island, USA, between 2030 and $3030 \mathrm{~m}$ asl (Figure 1). This dramatic landscape near the Haleakala crater rim offers a unique and harsh environment that is unsuitable for long-term or large-scale settlement. Nonetheless, numerous campsites provide evidence of repeated short-term visits associated with quarrying of a high-quality basalt source and collection of birds.

A transition between subalpine and alpine environments occurs at $2545 \mathrm{~m}$. The subalpine setting includes some diversity of trees and ground cover, whereas the alpine zone supports only sparse scattered shrubs. One intermittent stream is in the lower subalpine zone, and the only other fresh water is from rainfall or from moisture dripping in caves and rockshelters. Temperatures can drop near or below freezing in the alpine zone, especially at night.

At high elevation, near the crater rim and summit, the setting is exposed to strong winds from the north and east. As Macdonald et al. (1983:174) describe, the wind redistributes stony material when it "sometimes shrieks across the barren upper slopes of the mountain." Regardless of other weather conditions, the winds periodically impose limits upon human activities. For prehistoric and early historic use of the area, some sort of shelter was required either behind artificial stonework structures or inside natural caves or rockshelters.

Prior to the current work, just 1 radiocarbon date was available from an archaeological context in the high-altitude setting of Haleakalā. Based on this lone date, Kirch (1985:302) proposes that early temporary camping in this inhospitable area "informs us that the early Hawaiians thoroughly explored their island world, and did not confine their activities to the windward lowlands." The date is from the basal layer of a cave occupation near the lower inner western slope of the crater (Site 5050-11-3604), where Soehren (1963:126) reported a date of $1160 \pm 100 \mathrm{BP}$ for a sample of charcoal. The sample (Gak-325) was not corrected for ${ }^{13} \mathrm{C} /{ }^{12} \mathrm{C}$ isotope ratio, and early processing at the Gakushuin laboratory may have involved inadvertent error. The uncorrected result calibrates (at $2 \sigma$ or $95.4 \%$ confidence) within the range of AD 660-1030. The date suggests a possibility of early use of the area, but the exact date range must be regarded cautiously. 


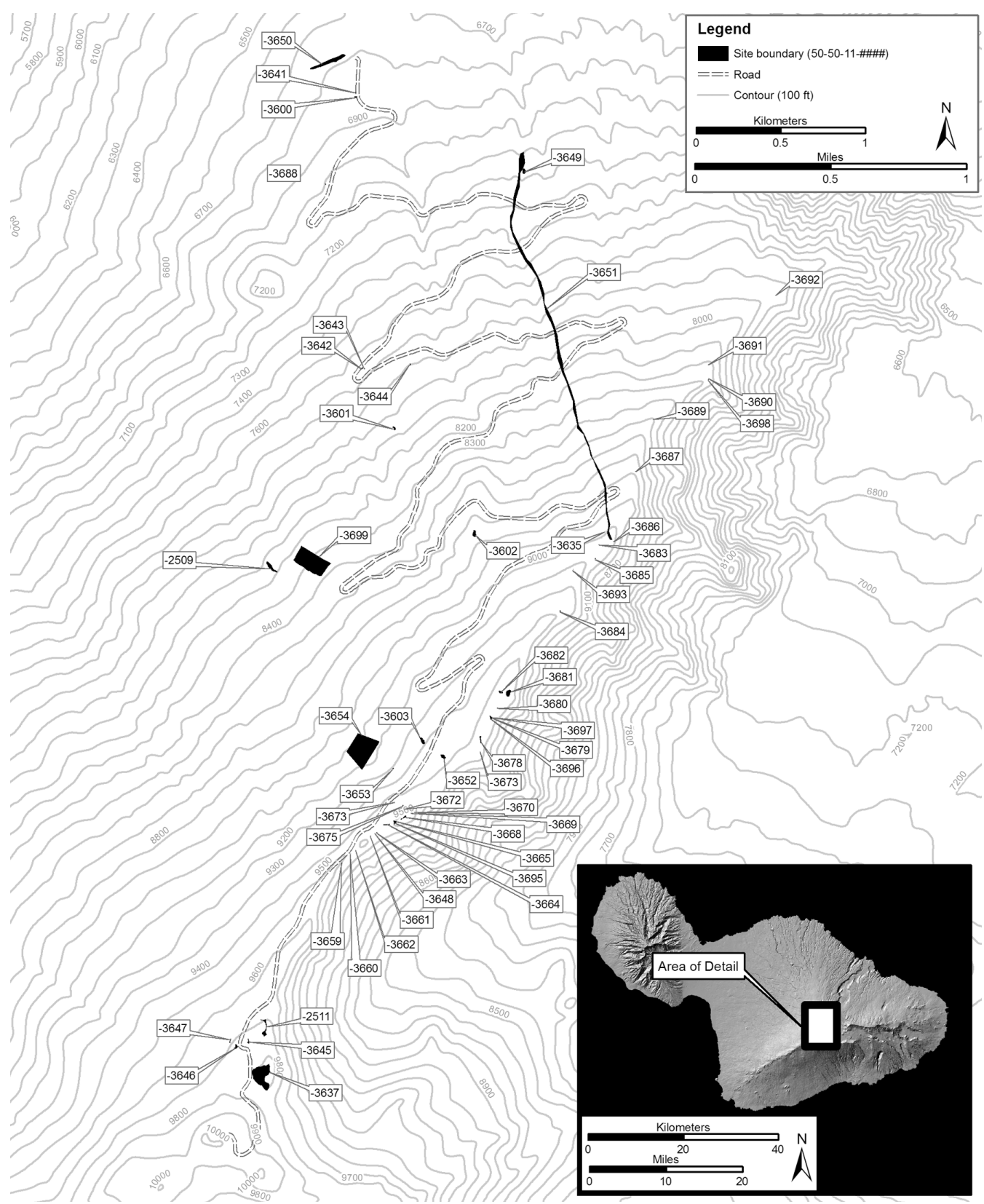

Figure 1 Location of study area showing site locations

Human occupation in the Hawaiian Islands was well established by AD 1000, and smaller scale use occurred perhaps as early as AD 700-800 (Athens et al. 2002; Carson 2005a, forthcoming; Masse and Tuggle 1998; Tuggle and Spriggs 2000). This assessment is based on robust syntheses of archaeological ${ }^{14} \mathrm{C}$ dates, genealogical reckoning, oral traditions of astronomical events, and a suite of paleoenvironmental data. Prior to the availability of these syntheses, other researchers have suggested a longer chronology extending to as early as the first centuries AD (Graves and Addison 1994; Hunt and Holsen 1991). 
Whether a "short" or "long" chronology is preferred, the study area at Haleakala may or may not contain preserved evidence of the earliest period of human occupation in the region. The earliest cultural deposits often were disturbed or obliterated by later occupations and by natural processes. Also, marginal areas, such as the alpine and upper subalpine zones at Haleakalā, most likely never contained more than a few isolated early sites. Nevertheless, Soehren's (1963:126) potentially early date is intriguing albeit problematic.

In a similar marginal high-altitude setting in Pohakuloa in Hawai' $i$ Island, Athens et al. (1991:75$76,81-82$ ) recognize the period of about AD 1400-1500 as the beginning of sudden, substantial use of short-term camps. Godby and Carson (2004:81) refer to this period as "a momentous turning point in the human use of this area [Pohakuloa], and this timing could relate to larger cultural processes in the region." Throughout the Hawaiian Islands, the period AD 1400-1500 appears to be associated with the creation of more numerous and larger communities, organized polities, and more intensive use of non-habitation zones (Athens and Kaschko 1989; Athens et al. 1991; Carson, forthcoming; Cordy 2004; Hommon 1976, 1986). A comparable date range may be proposed for the onset of intensive activities in the Haleakala study area.

A field investigation in 2005 documented 57 archaeological sites with 243 surface feature components, including 6 caves, 10 rockshelters, 18 surface scatters of basalt flakes, 161 enclosures, 3 platforms, 4 walls, 10 alignments, 25 cairns, 5 mounds, and 1 modified outcrop. At a sample of locations where subsurface cultural deposits were expected, 24 controlled excavation units provided essential data for stratigraphic sequencing, relative chronology, artifact and midden associations, and charcoal for ${ }^{14} \mathrm{C}$ dating. The details of this investigation are reported elsewhere (Carson and Mintmier 2006), and the present work concerns the ${ }^{14} \mathrm{C}$-based chronology.

\section{RESEARCH PROCEDURES}

The 24 excavation units included formats of $50 \times 50 \mathrm{~cm}$ or $50 \times 100 \mathrm{~cm}$ in plan view. Depths of excavations varied $10-70 \mathrm{~cm}$; most units were $\sim 40-50 \mathrm{~cm}$ deep. All units were excavated in arbitrary levels within natural strata, and the contents were screened through 1.6- $\mathrm{mm}$ wire mesh to ensure recovery of archaeological materials. A $25 \%$ sample of charcoal was retained, and all other cultural materials were collected from the screening.

Wood anatomist Gail Murakami examined samples of carbonized wood from the test excavations, and the specimens were identified to the lowest taxonomic level possible. The analysis involved examination of carbonized plant materials under a low-powered microscope, comparing the morphological structure of the specimens with the diagnostic features of a botanical reference collection. This procedure allowed identification wherever possible of short-lived plant taxa or plant parts most appropriate for ${ }^{14} \mathrm{C}$ dating to minimize the possible in-built old age of long-lived wood (Dye 2000).

${ }^{14} \mathrm{C}$ dating was performed at Beta Analytic (Miami, USA) for 12 samples of carbonized wood from the test excavations (samples Beta-209581 through -209592). With carbon isotope correction and application of standard atmospheric ${ }^{14} \mathrm{C}$ data (Stuiver et al. 2004), the conventional ${ }^{14} \mathrm{C}$ ages were calibrated in calendar years with the OxCal program (Bronk Ramsey 2001) at 2 standard deviations ( $2 \sigma$ or $95.4 \%$ confidence). 


\section{RADIOCARBON DATING RESULTS}

Twelve ${ }^{14} \mathrm{C}$ dates (Beta-209581 through -209592) from secure contexts provide a clear age-range distribution (Table 1, Figure 2). All samples were retrieved from defined firepits or clear concentrations of charcoal. Ten of the 12 dated specimens were of Styphelia tameiameia (pükiawe); this native shrub is considered a short-lived species. One sample (Beta-209592) was an unidentified pith or kernel; it is a short-lived anatomical part. Another (Beta-209590) was of Sophora chrysophylla (mämane); the wood of this native tree is possibly longer lived than the other dated specimens.

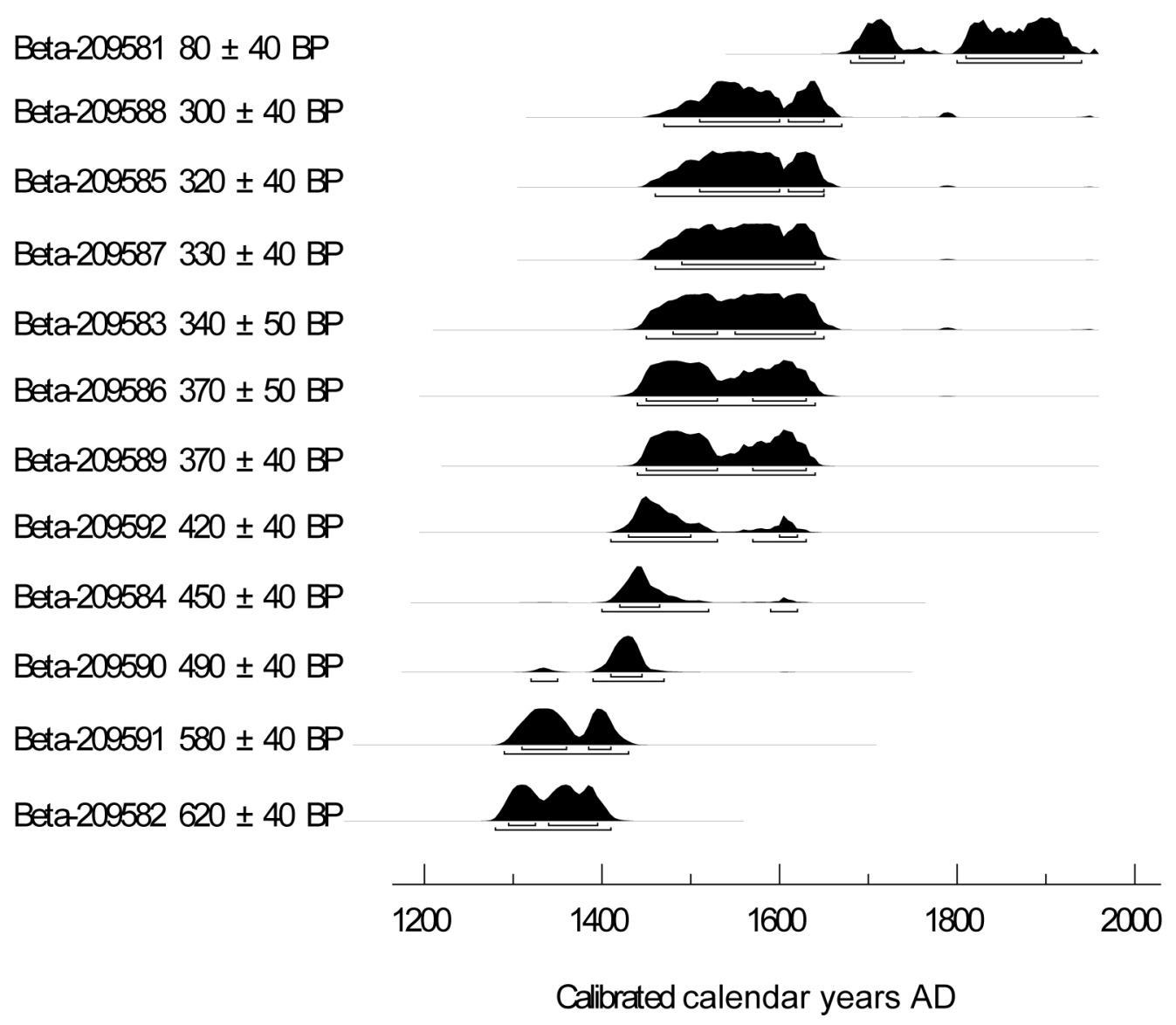

Figure 2 Probability distribution of ${ }^{14} \mathrm{C}$ dates. Calibration is by OxCal (Bronk Ramsey 2001) using standard atmospheric data for charcoal samples (Stuiver et al. 2004).

The earliest date (Beta-209582 at Site -3681) is cal AD 1280-1410, and another date (Beta-209589) from a different feature of the same site is cal AD 1440-1640. The earlier date is from a deposit rich with bird bones, adjacent to a platform where ritual offerings may have been made at the crater rim. The later date is from a deposit in a stone enclosure shelter associated with temporary camping in support of reduction of basalt from a nearby adze quarry (Site -2510).

At Feature 2 of Site $-2509,2{ }^{14} \mathrm{C}$ dates from a single firepit are in inverted stratigraphic order. The upper sample (Beta-209591) is cal AD 1290-1430, while the lower sample (Beta-209592) is cal AD $1410-1530$. If the 2 samples relate to the same event, then collectively they indicate a date around 


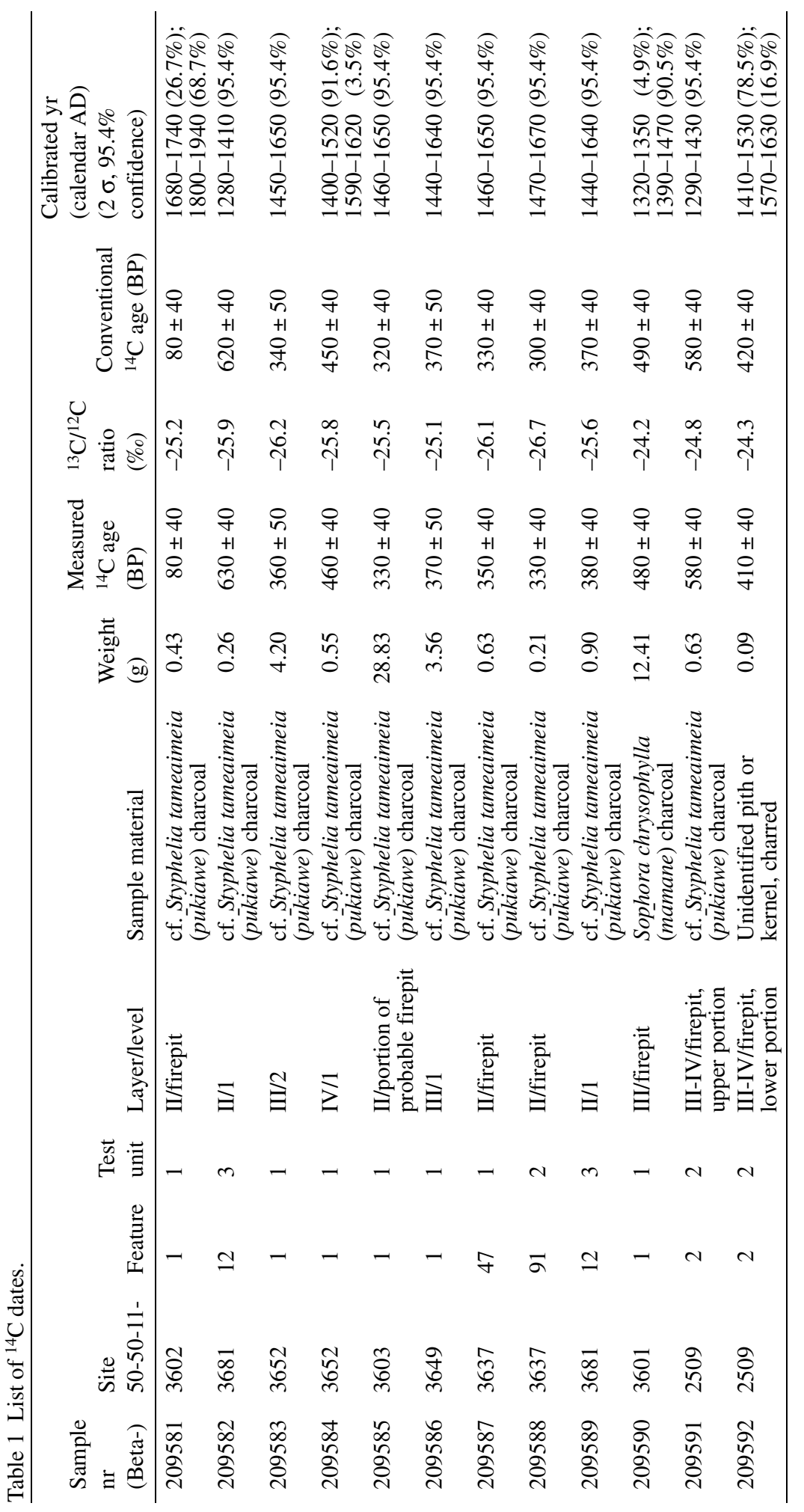


AD 1410-1430. However, repeated use of the firepit may have caused vertical mixing of material over an extended period, and the 2 dates could refer to separate camping episodes.

Charcoal in a firepit at Site -3601 yielded a date of cal AD 1390-1470 (Beta-209590). The date is for the upper portion of a cave deposit, while the lower portion is somewhat earlier. This result suggests a more refined range for the onset of widespread campsites in the project area. However, the sample material is wood from a tree (Sophora chrysophylla or mämane), and it could incorporate an in-built age that is slightly older than other dated specimens.

At Site -3652, 2 dates in stratigraphic order are cal AD 1400-1520 (Beta-209584) and cal AD 14501650 (Beta-209583). The 2 dates constrain one another, indicating earliest use of the area in the AD 1400 s.

A date of cal AD 1460-1650 (Beta-209585) refers to the earliest use of a cave at Site -3603. This result is consistent with an overall range of AD 1400-1600 for widespread, repeated camps in the project area. A similar date of cal AD 1440-1640 (Beta-209586) was obtained from Site -3649. The date is from a rockshelter in a much different setting than the other dated sites. The rockshelter overlooks an intermittent stream drainage at 7180 -ft elevation in the subalpine zone.

Camping occupations at 2 enclosure shelters at Site -3637 provided ${ }^{14} \mathrm{C}$ dates of cal AD $1460-1650$ (Beta-209587) and cal AD 1470-1670 (Beta-209588). The results are nearly identical, suggesting contemporary use of at least 2 features in separate parts of a large complex of 110 enclosures.

The latest ${ }^{14} \mathrm{C}$ date from a prehistoric deposit is from a firepit in Site -3602, cal AD 1680-1740 (26.7\%) or cal AD 1800-1940 (68.7\%). Given the prehistoric artifact association and lack of postcontact material, the later portion of the range seems unlikely.

These results overwhelmingly indicate a date range of AD 1400-1600 for the most intensive use of the project area, in the form of repeated short-term camps. Very limited activity occurred slightly earlier. Basalt quarrying and bird collection were among the main activities represented in the material record of this time range.

\section{PROPOSED CHRONOLOGICAL SYNTHESIS}

A chronological synthesis of activities in the study area proposes 7 general phases ranging from about AD 700 to the present. This outline is necessarily tentative, and future work may refine it with additional dates. The outline is proposed for this particular high-altitude setting in Maui, and it differs slightly from the sequences in other ecological zones of the Hawaiian Archipelago.

1. Foundation Phase, AD 700-1200: Although the earliest sites in the Hawaiian Archipelago date within the range of AD 700-1200 (Athens et al. 2002; Carson 2005a, forthcoming; Masse and Tuggle 1998; Tuggle and Spriggs 2000), no sites in the study area are of this age. The earliest sites were probably coastal-oriented, and they were most likely in favorable ecological settings. Population size was presumably small. Only very few prehistoric explorers may have entered the unwelcoming high-altitude environment at this time, and their activities generated little or no archaeological evidence.

2. Developmental Phase, AD 1200-1400: For this time range, several archaeological sites are known around Maui and other islands, and populations appear to be well established in most habitable areas. Short-term activity in the project area is evident only at Site -3681 at the crater rim, possibly involving ritual activity associated with collection of basalt material and birds. 
At Site -3681, a deposit (cal AD 1280-1410) was found that includes basalt flaking debris and abundant bird bones. The basalt flaking debris implies relation to a basalt adze quarry (Site -2510) in the crater floor. The bird bones indicate collection of birds in the high-altitude setting, probably targeting the Hawaiian petrels (Pterodroma phaeopygia sandwichensis or 'ua' $u$ ).

Activities during this phase and later were certainly short term and small scale due to limited water and food resources, and they were likely seasonal to take advantage of favorable weather conditions. Hawaiian petrels nest and hatch in caves and rockshelters in the alpine zone and crater floor in the warm and dry summer months. The same seasonal range offers the most favorable conditions for trips into this otherwise inhospitable environment.

3. Intensification Phase, AD 1400-1600: Nearly all of the dated cultural deposits in the study area relate to the general range of AD 1400-1600. In the early AD 1400s, at least a few caves and rockshelters (at Sites -2509, -3601, and -3652) contain evidence of temporary camps associated with basalt tool manufacture and bird collection. Basalt tool-making continued while bird collection declined later in this phase, as evidenced at the same sites and at Sites -3603 and -3681. Other temporary camps of less clear function also date to this phase, including a rockshelter at Site -3649 and 2 stone enclosures at Site -3637.

The phase AD 1400-1600 included the most intense use of the study area, largely in relation to a basalt adze quarry (Site -2510) in the inner western slopes of the crater. The numerous undated surface scatters of basalt flakes near the crater rim probably date to the same phase.

Throughout the archipelago, the time range of AD 1400-1600 appears to be associated with large population size, influencing settlement structure and land use patterns, political organization, and economic production and exchange systems (Athens and Kaschko 1989; Athens et al. 1991; Carson, forthcoming; Cordy 2004; Hommon 1976, 1986; Godby and Carson 2004:81; Kirch 1985:284-308; McCoy 2005). An overall trend includes increased use of non-habitation zones for intensive production of foods and other resources. In particular, marginal zones, such as the study area, were used most intensively during this period.

Activities in the marginal high-altitude project area occurred in the context of a growing population with increased demands for resources. A basalt quarry (Site -2510) and Hawaiian petrels represented desirable resources unique to this setting. Given the environmental constraints, resource access was limited to small groups of campers on long journeys, probably in the generally warm and dry summer months.

4. Equilibrium Phase, AD 1600-1778: This phase is defined in part by contact with Europeans in AD 1778. In the study area, most sites appear to support continued use of camps, and a cave at Site -3602 was perhaps first occupied at this time. Basalt flaking debris remains common, and bird bones are virtually absent from the cave and rockshelter deposits.

Elsewhere in Maui, Kolb $(1994,1997)$ suggested that construction of more numerous but smaller heiau (traditional Hawaiian religious sites) indicated a change toward community-based social and political systems. Kirch and Sharp (2005) specified this change around AD 1580-1640. Districtlevel or island-level polities no longer exerted the kinds of control over people and resources that they did in the prior period of about AD 1400-1600. The role of upland resource zones (as in the study area) probably did not diminish, but a change occurred in the way these places were perceived and managed. 
5. Early Historic Phase, AD 1778-1850: During the early postcontact era (AD 1778-1850), several important changes occurred in the Hawaiian Islands. In the first decades of this phase, pitched hostilities between powerful chiefs altered land tenure and land use, created large demand for economic products, and contributed to construction or modification of large monuments. Meanwhile, contact with foreign diseases contributed to significant population decline. In the middle to later part of this phase, internal social and political developments led to the abolishment of former religious practices, adoption of foreign religious systems, alteration of political organization to accommodate European standards, and the reapportionment of land as private properties. Also during this phase, the availability of foreign goods made traditional stone tools and some food products obsolete.

These events affected even remote places such as the study area. Nearly all of the prehistoric sites were abandoned at this time, but a few campsites accommodated continued use for a different set of reasons than previously considered. The demand for high-quality basalt diminished and eventually disappeared, thereby disabling one of the primary motivations for access to this area. Also, the overthrow of the former religious system negated a need for ritual sites and possible pilgrimages to the unique setting at the crater. At the same time, a new demand for sandalwood may have encouraged some use of the subalpine zone, and sandalwood-cutters may have traversed the alpine zone when traveling between different subalpine forested areas.

6. Late Historic Phase, AD 1850-1950: During the late historic phase, the study area was considered to be of little economic value. Some caves (Sites -3600 through -3602) and perhaps a few stone enclosure shelters were occupied by travelers with varied interests in the crater region. Cattle ranching made use of adjacent land, and cattle entered some parts of the study area. A long $(2.3 \mathrm{~km})$ cattle-driving wall of Site -3651 relates to this phase. Introduced goats vastly altered the native vegetation, probably necessitating the large stone-walled enclosures around Ralph Hosmer's forest-plating experiments in the early 1900s at Sites -3654 and -3699 (Kraebel 1922). In 1916, US Congress authorized the crater and its outer summit slopes as the Haleakala section of Hawaii National Park.

7. Modern Phase, about AD 1950 to present: Since AD 1950, the primary use of the project area has been for appreciation of natural and cultural resources, and the archaeological sites are recognized among these resources. Today, the United States National Park Service (NPS) owns and manages the area as part of Haleakala National Park. Although not officially authorized by NPS, some of the sites have been used in the modern era as brief rest stops or short-term camps.

\section{CONCLUSIONS}

The alpine and subalpine zones of Haleakala present a rugged and unwelcoming environment unsuitable for long-term or large-scale settlement, yet prehistoric Hawaiian campsites are evident in the archaeological record. The campsites appear to be associated with quarrying of a high-quality basalt source and also the collection of birds. Archaeological excavations provide hard evidence for the antiquity of these sites based on ${ }^{14} \mathrm{C}$ dates for charcoal of short-lived specimens obtained from secure contexts.

Prior to the current work, a single problematic ${ }^{14} \mathrm{C}$ date outside the study area raised the possibility of early use of the upland marginal ecological setting at Haleakalā. Soehren (1963:126) reported sample Gak-325 with a measured (uncorrected) age of $1160 \pm 100$ BP. A similar date could not be replicated by the present study. 
The earliest secure date (Beta-209582: $630 \pm 40 \mathrm{BP}$ ) is from Site -3681 , situated at $2880 \mathrm{~m}$ by the crater rim in the alpine zone. The 2- $\sigma$ calibrated range is AD 1280-1410, and it relates to a deposit containing basalt flaking debris and abundant bird bones. The basalt flaking debris implies relation to a basalt adze quarry (Site -2510) near the crater floor. The bones indicate collection of birds in the high-altitude setting, probably targeting the Hawaiian petrels (Pterodroma phaeopygia sandwichensis or 'ua' $u$ ).

The current data provide a solid comparative baseline for future investigations at other sites in the alpine and subalpine zones at Haleakalā. For instance, the chronological sequence at the basalt quarry (Site -2510) has yet to be studied directly, as this site was outside the scope of work for the present project. Future investigation may yield slightly earlier dates than have been documented thus far.

Nearly all of the new dates calibrate in some part of the general range of about AD 1400-1600. Numerous campsites were scattered along the crater rim and the lower western slopes of the mountain and were used repeatedly until perhaps some time in the early 1800s.

The phase AD 1400-1600 is consistent with archipelago-wide dates for intensified economic production and expansion into marginal resource zones (Athens and Kaschko 1989; Athens et al. 1991; Carson 2005b,c, forthcoming; Cordy 2004; Hommon 1976, 1986; Godby and Carson 2004:81; Kirch 1985:284-308; McCoy 2005). The current study emphasizes that this phase is crucial for understanding the development of traditional Hawaiian social, economic, and political systems.

\section{ACKNOWLEDGMENTS}

This work is based on investigations conducted by the authors for International Archaeological Research Institute, Inc. (IARII), in accordance with Task Order T8298050002 of Indefinite Quantity Contract C8298030001 issued by the National Park Service (NPS). J Stephen Athens was the principal investigator for IARII, and Elizabeth Gordon represented cultural resource management concerns of the Haleakala National Park. The present work does not necessarily reflect the opinions of the NPS or IARII.

\section{REFERENCES}

Athens JS, Kaschko MW. 1989. Prehistoric upland bird hunters: archaeological inventory survey and testing for the MPRC Project Area and the Bobcat Trail Road, Pohakuloa Training Area, Island of Hawai'i [report prepared for U.S. Army Engineer District, Pacific Ocean Division]. Honolulu: International Archaeological Research Institute, Inc.

Athens JS, Kaschko MW, James HF. 1991. Prehistoric bird hunters: high altitude resource exploitation on Hawai'i Island. Bishop Museum Occasional Papers 31:63-84.

Athens JS, Tuggle HD, Ward JV, Welch DJ. 2002. Avifaunal extinctions, vegetation change, and Polynesian impacts in prehistoric Hawai'i. Archaeology in Oceania 37:57-78.

Bronk Ramsey C. 2001. Development of the radiocarbon program OxCal. Radiocarbon 43(2A):355-63.

Carson MT. 2005a. A radiocarbon dating synthesis for Kaua'i. In: Carson MT, Graves MW, editors. Na Mea Kahiko o Kaua'i: Archaeological Studies in Kaua'i.

Special Publication No. 2. Honolulu: Society for Hawaiian Archaeology. p 11-32.

Carson MT. 2005b. 'Alekoko fishpond. In: Carson MT, Graves MW, editors. Na Mea Kahiko o Kaua'i: Archaeological Studies in Kaua'i. Special Publication No. 2. Honolulu: Society for Hawaiian Archaeology. p 66-71.

Carson MT. 2005c. Halele'a agricultural systems reconsidered. In: Carson MT, Graves MW, editors. Na Mea Kahiko o Kaua' $i$ : Archaeological Studies in Kaua' $i$. Special Publication No. 2. Honolulu: Society for Hawaiian Archaeology. p 109-16.

Carson MT. Forthcoming. Timing of colonisation, land use chronology, and implications for palaeodemography in Kaua'i, Hawaiian Islands. Journal of the Polynesian Society 115.

Carson MT, Mintmier MA. 2006. Archeological site documentation in Front Country areas in the Summit District of Haleakalā National Park, Maui Island, Hawai 'i [draft report prepared for National Park Service]. Ho- 
nolulu: International Archaeological Research Institute, Inc.

Cordy R. 2004. Considering archaeological indicators of the rise of appointed chiefs and the feudal land system in the Hawaiian Islands. Hawaiian Archaeology 9:124.

Dye TS. 2000. Effects of ${ }^{14} \mathrm{C}$ sample selection in archaeology: an example from Hawai 'i. Radiocarbon 42(2): 203-17.

Godby WC, Carson MT. 2004. An overview of the archaeological context of Pohakuloa training area in $\mathrm{Ha}-$ wai 'i Island. Hawaiian Archaeology 9:74-82.

Graves MW, Addison DJ. 1994. The Polynesian settlement of the Hawaiian Archipelago: integrating models and methods in archaeological interpretation. World Archaeology 26:380-99.

Hommon RJ. 1976. The formation of primitive states in pre-contact Hawaii [PhD dissertation]. Tucson: University of Arizona.

Hommon RJ. 1986. Social evolution in ancient Hawaii. In: Kirch PV, editor. Island Societies: Archaeological Approaches to Evolution and Transformation. New Directions in Archaeology. Cambridge: Cambridge University Press. p 55-68.

Hunt TL, Holsen RM. 1991. An early radiocarbon chronology for the Hawaiian Islands: a preliminary analysis. Asian Perspectives 30:147-61.

Kirch PV. 1985. Feathered Gods and Fishhooks: An Introduction to Hawaiian Archaeology and Prehistory. Honolulu: University of Hawai 'i Press. 360 p.

Kirch PV, Sharp WD. 2005. Coral ${ }^{230}$ Th dating of the imposition of a ritual control hierarchy in precontact $\mathrm{Ha}$ waii. Science 307:102-4.

Kolb MJ. 1994. Monumentality and the rise of religious authority in precontact Hawaii. Current Anthropology
35:521-47.

Kolb MJ. 1997. Labor mobilization, ethnohistory, and the archaeology of community in Hawai 'i. Journal of Archaeological Method and Theory 4:265-85.

Macdonald GA, Abbott AT, Peterson FL. 1983. Volcanoes in the Sea: The Geology of Hawaii. 2nd edition. Honolulu: University of Hawai 'i Press. 528 p.

Masse WB, Tuggle HD. 1998. The date of Hawaiian colonization. In: Stevenson CM, Lee G, Morin FP, editors. Easter Island in Pacific Context South Seas Symposium: Proceedings of the Fourth International Conference on Easter Island and East Polynesia. Easter Island Foundation Occasional Paper No. 4. Los Osos, California: Bearsville Press and Cloud Mountain Press. p 229-35.

McCoy MD. 2005. The development of the Kalaupapa field system, Moloka'i Island, Hawai 'i. Journal of the Polynesian Society 114:339-58.

Soehren LJ. 1963. An archaeological survey of portions of east Maui, Hawaii [report prepared for National Park Service]. Honolulu: Department of Anthropology, Bernice P. Bishop Museum.

Stuiver PJ, Baillie MGL, Bard E, Bayliss A, Beck JW, Bertrand CJH, Blackwell PG, Buck CE, Burr GS, Cutler KB, Damon PE, Edwards RL, Fairbanks RG, Friedrich M, Guilderson TP, Hogg AG, Hughen KA, Kromer B, McCormac G, Manning S, Bronk Ramsey C, Reimer RW, Remmele S, Southon JR, Stuiver M, Talamo S, Taylor FW, van der Plicht J, Weyhenmeyer CE. 2004. IntCal04 terrestrial radiocarbon age calibration, 0-26 cal kyr BP. Radiocarbon 46(3):1029-58.

Tuggle HD, Spriggs M. 2000. The age of the Bellows Dune site O18, O'ahu, Hawai' $\mathrm{i}$, and the antiquity of Hawaiian colonization. Asian Perspectives 39:16588. 